\title{
REALISTIC LEVELS OF A FERTILIZER IMPAIR IBERIAN NEWT EMBRYONIC DEVELOPMENT
}

\author{
Manuel E. Ortiz-Santaliestra ${ }^{1,4}$, Adolfo Marco ${ }^{2}$, and Miguel Lizana ${ }^{3}$ \\ ${ }^{1}$ Instituo de Investigación en Recursos Cinegéticos UCLM-CSIC-JCCM, Ciudad Real, 13071, Spain \\ ${ }^{2}$ Estación Biológica de Doñana CSIC, Sevilla, 41092, Spain \\ ${ }^{3}$ Universidad de Salamanca, Salamanca, 37007, Spain
}

\begin{abstract}
Aвstract: A wide variety of agricultural chemicals with potential to affect amphibian health are released into the environment daily. Most of these chemicals are xenobiotic compounds that are highly toxic to embryos, tadpoles, and terrestrial stages. Other substances that occur in pristine environments at harmless concentrations, such as inorganic nitrogenous compounds, may reach potentially toxic levels as a consequence of certain human activities, including the application of fertilizers. Most of the studies that analyze the effects of inorganic nitrogen on amphibian embryos are conducted with anurans, whereas little information exists regarding urodeles. Embryos of newts and salamanders usually exhibit longer times to hatch than frogs and toads. A longer hatching time results in a longer exposure of embryos to diffuse environmental pollution and therefore a higher risk of suffering toxic effects during the embryonic stage. We demonstrate that ammonium nitrate, a widely used nitrogenous fertilizer, at concentrations used in areas of high agricultural intensity, affects embryonic development of the Iberian newt (Lissotriton boscai). Although ammonium nitrate did not have significant lethal effects, it reduced the growth rate of exposed embryos, which were $9.6 \%$ smaller than controls. Hatching synchrony remained similar across treatments, and hatching date was not affected by ammonium nitrate, indicating that the effect on growth was not timedependent. Researchers have demonstrated fitness costs in smaller than average tadpoles, suggesting that ammonium nitrate exposure could have long-term negative consequences for the Iberian newt.
\end{abstract}

Key words: Amphibians; Embryonic development; Environmental pollution; Hatching traits; Lissotriton boscai; Nitrogen fertilizers

Environmental pollution is listed among the primary causes of global amphibian decline (e.g., Beebee and Griffiths, 2005). Most amphibian ecotoxicological studies are focused on the analysis of the effects of xenobiotic compounds, artificial substances whose presence in the environment is a consequence of human activities. Xenobiotic compounds have received special attention because their toxicity is usually high and their mechanisms of action are sometimes unknown or poorly understood (e.g., Mann et al., 2009). However, some chemicals that occur naturally in pristine environments at harmless levels also may cause serious damage to organisms when their concentrations become excessively high. One of the most typical cases of potential toxicity by excess is that of inorganic nitrogen (Driscoll, 2003; Galloway et al., 2002).

The input of chemical fertilizers constitutes the main anthropogenic source of nitrogen to the environment (Vitousek et al., 1997), and this use of fertilizers has increased disproportionately over the past five decades in response to demands for food and fiber crops (Holland et al., 2005). Much of the nitrogen applied as fertilizer is not used by plants at the point of application and can flow laterally over impermeable soil layers, or via groundwater basins, into freshwater lakes or rivers (Crews and Peoples, 2004). In aquatic ecosystems, 
excess inorganic nitrogen can cause declines in species richness and changes in community composition via increased productivity, acidification, or direct toxicity on certain organisms (Camargo and Alonso, 2006).

Excess nitrogen in water bodies can seriously harm amphibian aquatic stages (e.g., Ortiz et al., 2004). Embryos and tadpoles may be more sensitive to water pollution than other aquatic vertebrates due to their permeable skin (Beebee, 1996). In addition, the gelatinous envelope that protects eggs from mechanical damage is permeable to many chemical substances (Dunson et al., 1992). Moreover, fields are often fertilized in spring, at the same time that amphibians from temperate regions are breeding and then laying their eggs. Environmentally realistic ammonium $\left(\mathrm{NH}_{4}^{+}\right)$or nitrate $\left(\mathrm{NO}_{3}{ }^{2}\right)$ concentrations in water bodies influenced by agricultural activities are likely to damage amphibian eggs and larvae (Marco and OrtizSantaliestra, 2009, and references therein). For example, Ballester (2003) reported environmental concentrations of nitrate (expressed as nitrogen from nitrate) up to $36.6 \mathrm{mg} \mathrm{N}-\mathrm{NO}_{3}{ }^{2} / \mathrm{L}$ in water bodies in which amphibians breed in southeastern Spain. These concentrations have been demonstrated to cause anorexia on Pelophylax perezi tadpoles inhabiting those polluted environments (Egea-Serrano et al., 2009).

An excess of inorganic nitrogen could affect amphibian embryos in several ways. For example, cations such as ammonium inhibit the hatching enzyme responsible for degradation of the egg membrane, which allows the elongation of the inner space of the egg over time (Yoshizaki, 1978). Hence, inhibition of the enzyme limits the space available for the embryo to grow. As a consequence, the embryo can suffer spinal curvatures that lead to anatomical malformations and ultimately to death (Freda and Dunson, 1985). The assimilation of nitrate or ammonium ions forces organisms to activate detoxification mechanisms to eliminate the excess nitrogen from the body. Although no published information exists on nitrogen detoxification mechanisms in amphibian embryos, tadpoles use a variety of pathways that require high inputs of energy (Wright and Wright, 1996). Such an energet- ically costly mechanism likely affects growth and could therefore lead to smaller hatchlings, potentially compromising survival during the larval stage (Semlitsch and Gibbons, 1990). In addition, nitrate that is ingested (which could apply to hatchlings or older individuals but not embryos) may be reduced to nitrite $\left(\mathrm{NO}_{2}{ }^{2}\right)$ in the large intestine where it then enters the bloodstream (Kross et al., 1992). In the blood, nitrite reacts with hemoglobin and oxidizes ferrous iron to ferric iron, thus producing methemoglobin. Methemoglobin cannot bind or transport oxygen and thus causes tissue hypoxia and death (Huey and Beitinger, 1980).

We hypothesize that ammonium and nitrate found in areas of high fertilizer use might reduce the survival and delay growth and development of urodele embryos. Although there is a growing body of literature reporting the negative effects of inorganic nitrogen on amphibian embryos (e.g., Diamond et al., 1993; Jofre and Karasov, 1999; Jofre et al., 2000; Massal et al., 2007; Puglis and Boone, 2007; Schuytema and Nebeker, 1999a), the information regarding urodeles is still very scarce. The published papers indicate a high tolerance of salamander embryos to inorganic nitrogen in terms of mortality. Laposata and Dunson (1998) observed that mortality rate of Ambystoma maculatum and $A$. jeffersonianum exposed to nitrate concentrations from 0 to $9.03 \mathrm{mg} \mathrm{N}-$ $\mathrm{NO}_{3}{ }^{2} / \mathrm{L}$ did not vary significantly. Meredith and Whiteman (2008) did not find significant mortality of A. mexicanum embryos at $500 \mathrm{mg}$ $\mathrm{N}-\mathrm{NO}_{3}{ }^{2} / \mathrm{L}$. Griffis-Kyle and Ritchie (2007) exposed $A$. tigrinum embryos to average concentrations of $18 \mathrm{mg} \mathrm{N} / \mathrm{L}$ (combining ammonium, nitrate, and nitrite) in field enclosures and found no significant mortality either. Ortiz-Santaliestra et al. (2007, 2011) found no lethal effects of ammonium nitrate $\left(\mathrm{NO}_{3} \mathrm{NH}_{4}\right)$ at $45.2 \mathrm{mg} \mathrm{N}-\mathrm{NH}_{4}^{+} / \mathrm{L}$ on Triturus pygmaeus and Chioglossalusitanica embryos. Even when nitrite, a more toxic form than nitrate or ammonium, has been used as nitrogen source, little effects on embryonic mortality have been reported. Griffis-Kyle (2005) exposed A. tigrinum tigrinum eggs to nitrite concentrations between 0 and $6.1 \mathrm{mg} \mathrm{N}-\mathrm{NO}_{2}{ }^{2} / \mathrm{L}$, and he 
observed no effects during the embryonic stage, with hatching rates always - 86\%; however, exposure as embryos significantly reduced larval survival, demonstrating a delayed effect on mortality.

Sublethal effects of inorganic nitrogen on urodele embryos have been reported more often than lethal effects. Ortiz-Santaliestra et al. (2007) observed that ammonium nitrate at $45.2 \mathrm{mg} \mathrm{N}-\mathrm{NH}_{4}{ }^{+} / \mathrm{L}$ reduced length and developmental stage at hatching of Triturus pygmaeus. Meredith and Whiteman (2008) showed that the higher nitrate concentrations they used (300-500 $\mathrm{mg} \mathrm{N}-\mathrm{NO}_{3}{ }^{2} / \mathrm{L}$ ) delayed hatching of $A$. mexicanum larvae. Ortiz et al. (2004) exposed Pleurodeles waltl to $45.2 \mathrm{mg}$ $\mathrm{N}-\mathrm{NH}_{4}{ }^{+} / \mathrm{L}$ as ammonium nitrate for $15 \mathrm{~d}$, from embryos to early larval stages; the fertilizer reduced the growth rates of individuals, although whether this effect occurred during the embryonic or during the larval exposure could not be elucidated. Similar results have been obtained when analyzing the sublethal effects of nitrite on urodele embryos. Griffis-Kyle (2007) observed that nitrite increased $A$. tigrinum hatching asynchrony by delaying hatching at concentrations $>2 \mathrm{mg}$ $\mathrm{N}-\mathrm{NO}_{2}{ }^{2} / \mathrm{L}$ and accelerated hatching at concentrations above that level. Developmental stage and length at hatching of $A$. tigrinum also were negatively affected by nitrite levels up to $6.1 \mathrm{mg} \mathrm{N}-\mathrm{NO}_{2}{ }^{2} / \mathrm{L}$ (Griffis-Kyle, 2007).

Our objectives were to test the effects of ammonium nitrate, one of the most commonly used fertilizers worldwide, at concentrations found in areas of high fertilizer use on survival, growth, and development of Iberian newt (Lissotriton boscai). Lissotriton boscai may be especially sensitive to aquatic nitrogen pollution because it is primarily aquatic, and it has become rare in areas of intense agricultural activity in Spain and Portugal (DíazPaniagua, 2009), both of which suggest that it has high sensitivity to certain agrochemicals. In addition, inorganic nitrogen is toxic to adult L. boscai during their terrestrial life (OrtizSantaliestra et al., 2005), and it changes their reproductive behavior by shortening the duration of male's tail-fanning movements and by decreasing female responsiveness during courtship (Ortiz-Santaliestra et al., 2009).

\section{Materials and Methods}

The embryos tested in the experiment were laid by females collected from a natural area and kept in captivity for a few days. Ten L. boscai gravid females were collected in March 2004 from a pond in Miranda del Castañar (Salamanca, Spain: 40u299120N, 5u599390W; datum WGS84) in the low part of a mountain valley covered by oak (Quercus spp.) and chestnut (Castanea spp.) trees with a humid Mediterranean climate. Nitrate and ammonium levels were measured at the moment of newt collection by titration methods (tests Visocolor ECO 931041 and 931008, respectively; Macherey-NagelH, Düren, Germany). Nitrate concentrations varied from 1.7 to $2.3 \mathrm{mg} \mathrm{N}-\mathrm{NO}_{3}{ }^{2} / \mathrm{L}$, whereas ammonium varied from 0.2 to $0.4 \mathrm{mg} \mathrm{N}-\mathrm{NH}_{4}^{+} / \mathrm{L}$. We used newts from this pool because the low nitrogen levels permitted us to avoid possible phenomena of local adaptation by individuals to excessive inorganic nitrogen. Gravid females were recognized by observing the formed eggs through the skin in the inguinal region. The average mass of females was $1.75 \mathrm{~g}$ (range, 1.22-2.27 g) and the average snoutvent length (SVL) was $38.7 \mathrm{~mm}$ (range, 36.6$40.3 \mathrm{~mm}$ ). The females were transported to the laboratory and placed individually in aquaria with $3 \mathrm{~L}$ of water that was filtered with activated carbon. Air temperature in the laboratory was kept at $206 \mathrm{luC}$, and windows provided exposure to the natural photoperiod. Newts were kept in the aquaria for $3 \mathrm{~d}$, during which they were fed daily with frozen chironomid larvae (MBF Bvba, Essen, Belgium). Every day, we collected the eggs that were laid. We did not find any relationship between female's mass and number of eggs laid, although given the short period during which newts were kept in the laboratory, this does not necessarily represent what would happen if we had considered the whole reproductive period.

The experiments were performed in 12 aquaria containing $0.5 \mathrm{~L}$ of water filtered with activated carbon to remove nitrate, ammonium, and chloride. In each aquarium, we placed five eggs that had been laid by different females and that were selected randomly to remove female-related biases. Experimental aquaria were randomly assigned 
to a nominal concentration of ammonium nitrate $\left(0,11.3\right.$, or $\left.45.2 \mathrm{mg} \mathrm{N}-\mathrm{NH}_{4}^{+} / \mathrm{L}\right)$. The lowest concentration was selected from the nitrate legal maximum allowed for drinking waters (European Council, 1998). The highest concentration was selected in accordance with nitrogen concentrations measured in amphibian-inhabited ponds from central Spain that are influenced by agricultural runoff (OrtizSantaliestra et al., 2010). Thus, every treatment was replicated four times. To monitor correctly the hatching times, the replication system in every treatment was designed as follows: one replicate contained eggs laid during the first day after the collection of the females, one replicate contained eggs laid during the second day, and two replicates contained eggs laid during the third day. Therefore, the exposure always began within the first $24 \mathrm{~h}$ after egg deposition. The experiment lasted for $20 \mathrm{~d}$, the time necessary for all the surviving embryos to hatch.

We prepared a stock solution with ammonium nitrate salt (99\% pure; Merck, Darmstaad, Germany) and pipetted the corresponding volumes of this solution into the experimental tanks to obtain the nominal concentrations of ammonium nitrate. To minimize the variations in nitrogen levels, we used a static renewal design with $100 \%$ of water renewal and readjustment of ammonium nitrate concentrations every day. At days 10 and 20 of the experiment, before changing the water, we analyzed ammonium and nitrate levels in all the aquaria by titration (tests Visocolor ECO 931041 and 931008, respectively; Macherey-Nagel). Nitrate concentrations $(\mathbf{6 1} \mathrm{SE})$ by treatment were 0.360 .1 , 10.060 .1 , and $42.360 .3 \mathrm{mg} \mathrm{N}-\mathrm{NO}_{3}{ }^{2} / \mathrm{L}$. Ammonium concentrations (61 SE) by treatment were $0.260 .1,9.560 .2$, and 41.46 $0.1 \mathrm{mg} \mathrm{N}-\mathrm{NH}_{4}^{+} / \mathrm{L}$. Water $\mathrm{pH}$ was monitored daily with a $\mathrm{pH}$ meter (Hanna HI-8314Nt; Hanna Instruments, Eibar, Spain). Water $\mathrm{pH}$ throughout the experiment varied between 7.20 and 7.40, and no significant variations among experimental aquaria were found (analysis of variance [ANOVA]: $F_{2,9} 50.268$, P 5 0.771).

We checked the aquaria daily and noted the number of dead embryos. We calculated mortality rate as the number of dead embryos at the end of the experiment, when all the survivors had hatched, divided by the initial number of individuals. Within the first $24 \mathrm{~h}$ after hatching, we measured the total length (mouth to tail tip) of every hatchling with a digital caliper ACHA 17²64 (d 50.01 mm; ACHA, Eibar, Spain) and recorded its developmental stage according to Harrison (1969). We calculated the standard deviation of the hatching time in each aquarium and used it as a hatching asynchrony index. To meet the assumptions of parametric statistics, we transformed mortality rates using arcsine of the square root. Time, length, and stage at hatching, as well as asynchrony index, were log transformed. We used arcsine of square root and logarithm transformations as recommended, respectively, for rates and for linear variables obtained from counts (Sokal and Rohlf, 1995). To analyze the effects of ammonium nitrate on embryonic mortality, hatching time, and asynchrony index, we used univariate ANOVAs with the fertilizer concentration as the categorical factor. The length and the stage at hatching were analyzed with analyses of the covariance, with the transformed hatching time as a covariate. Data for all the dependent values were average values for each experimental aquarium. We used an a value of 0.05 as the significance level in all the analyses, although we considered $P$ values between 0.05 and 0.1 as marginally significant. When results were significant, we used honestly significant difference (HSD) Tukey post-hoc tests to control for multiple pairwise comparisons. For all statistical analyses, we used SPSS 11.5 for Windows software (SPSS Inc., Chicago, IL, USA).

\section{Results}

Mean mortality rates (61 SE) were 5.06 $5.0 \%$ among controls, $11.266 .6 \%$ at $11.3 \mathrm{mg}$ $\mathrm{N}-\mathrm{NH}_{4}{ }^{+} / \mathrm{L}$, and $20.068 .2 \%$ at $45.2 \mathrm{mg} \mathrm{N}-$ $\mathrm{NH}_{4}{ }^{+} / \mathrm{L}$. In spite of this slight increase of mortality as the concentration of ammonium nitrate increased (Fig. 1), the ANOVA did not show any statistically significant effect of the fertilizer on embryonic mortality (Table 1).

The effects of ammonium nitrate on hatching time and hatching asynchrony did not vary significantly by concentration (Тa- 


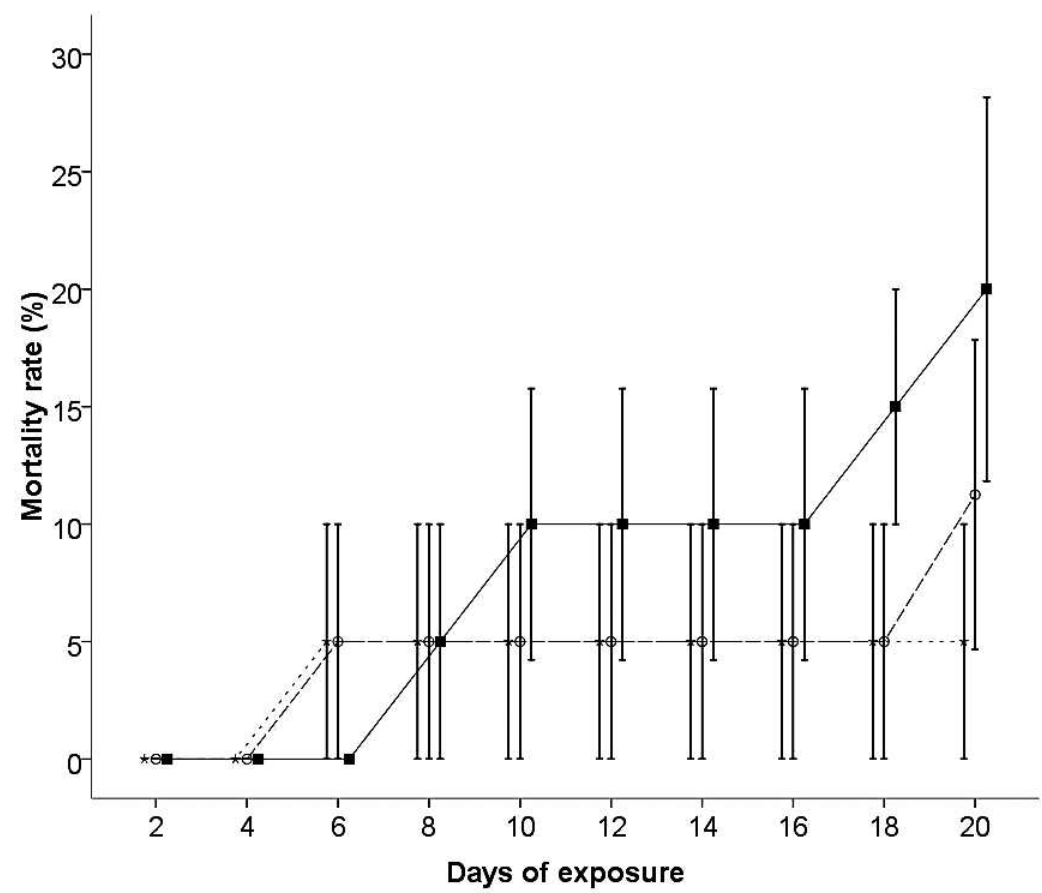

FIG. 1.-Mortality rates (61 SE) of Lissotriton boscai embryos exposed to different concentrations of ammonium nitrate.

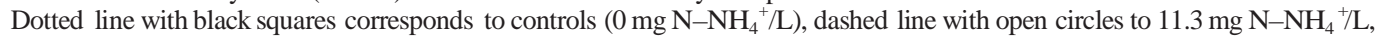
and continuous line with asterisks to $45.2 \mathrm{mg} \mathrm{N}-\mathrm{NH}_{4}{ }^{+} / \mathrm{L}$. No significant differences among treatments were detected.

ble 1). However, there was a trend in which embryos exposed to the lower ammonium nitrate concentration hatched, on average, $1.3 \mathrm{~d}$ earlier than controls, whereas those exposed to the higher concentration hatched 1.7 d later than controls (Fig. 2a). Likewise, mean hatching asynchrony tended to be greater in control individuals, with an asynchrony index greater than $3 \mathrm{~d}$, than in ammonium nitrate-treated embryos, with an asynchrony index lower than $3 \mathrm{~d}$ (Fig. 2b).

The mean developmental stage at which embryos exposed to $11.3 \mathrm{mg} \mathrm{N}-\mathrm{NH}_{4}{ }^{+} / \mathrm{L}$ hatched tended to be lower than that shown

TABLE 1.- Results of statistical analyses to test the effects of ammonium nitrate $\left(\mathrm{NO}_{3} \mathrm{NH}_{4}\right)$ on mortality and hatching variables of Lissotriton boscai embryos.

\begin{tabular}{|c|c|c|c|c|c|}
\hline Variable & Source of variation & Sum of squares & df & $\mathrm{F}$ & $P$ \\
\hline \multirow[t]{2}{*}{ Mortality $^{\mathrm{a}}$} & $\mathrm{NO}_{3} \mathrm{NH}_{4}$ & 0.1653 & 2 & 1.134 & 0.364 \\
\hline & Error & 0.6558 & 9 & & \\
\hline \multirow[t]{2}{*}{ Hatching time ${ }^{b}$} & $\mathrm{NO}_{3} \mathrm{NH}_{4}$ & 0.0242 & 2 & 1.430 & 0.289 \\
\hline & Error & 0.0761 & 9 & & \\
\hline \multirow[t]{2}{*}{ Hatching asynchrony ${ }^{\mathrm{b}}$} & $\mathrm{NO}_{3} \mathrm{NH}_{4}$ & 0.0122 & 2 & 0.129 & 0.881 \\
\hline & Error & 0.4244 & 9 & & \\
\hline \multirow[t]{3}{*}{ Stage at hatching ${ }^{c}$} & Hatching time ${ }^{\mathrm{d}}$ & 0.0004 & 1 & 18.383 & 0.003 \\
\hline & $\mathrm{NO}_{3} \mathrm{NH}_{4}$ & 0.0002 & 2 & 3.286 & 0.091 \\
\hline & Error & 0.0002 & 8 & & \\
\hline \multirow[t]{3}{*}{ Length at hatching ${ }^{c}$} & Hatching time ${ }^{\mathrm{d}}$ & 0.0002 & 1 & 0.651 & 0.453 \\
\hline & $\mathrm{NO}_{3} \mathrm{NH}_{4}$ & 0.0042 & 2 & 6.099 & 0.025 \\
\hline & Error & 0.0028 & 8 & & \\
\hline
\end{tabular}

\footnotetext{
according to the repeated measures analysis of the variance.

b According to the univariate analysis of the variance.

c According to the univariate analysis of the covariance.

${ }^{\mathrm{d}}$ Covariate.
} 

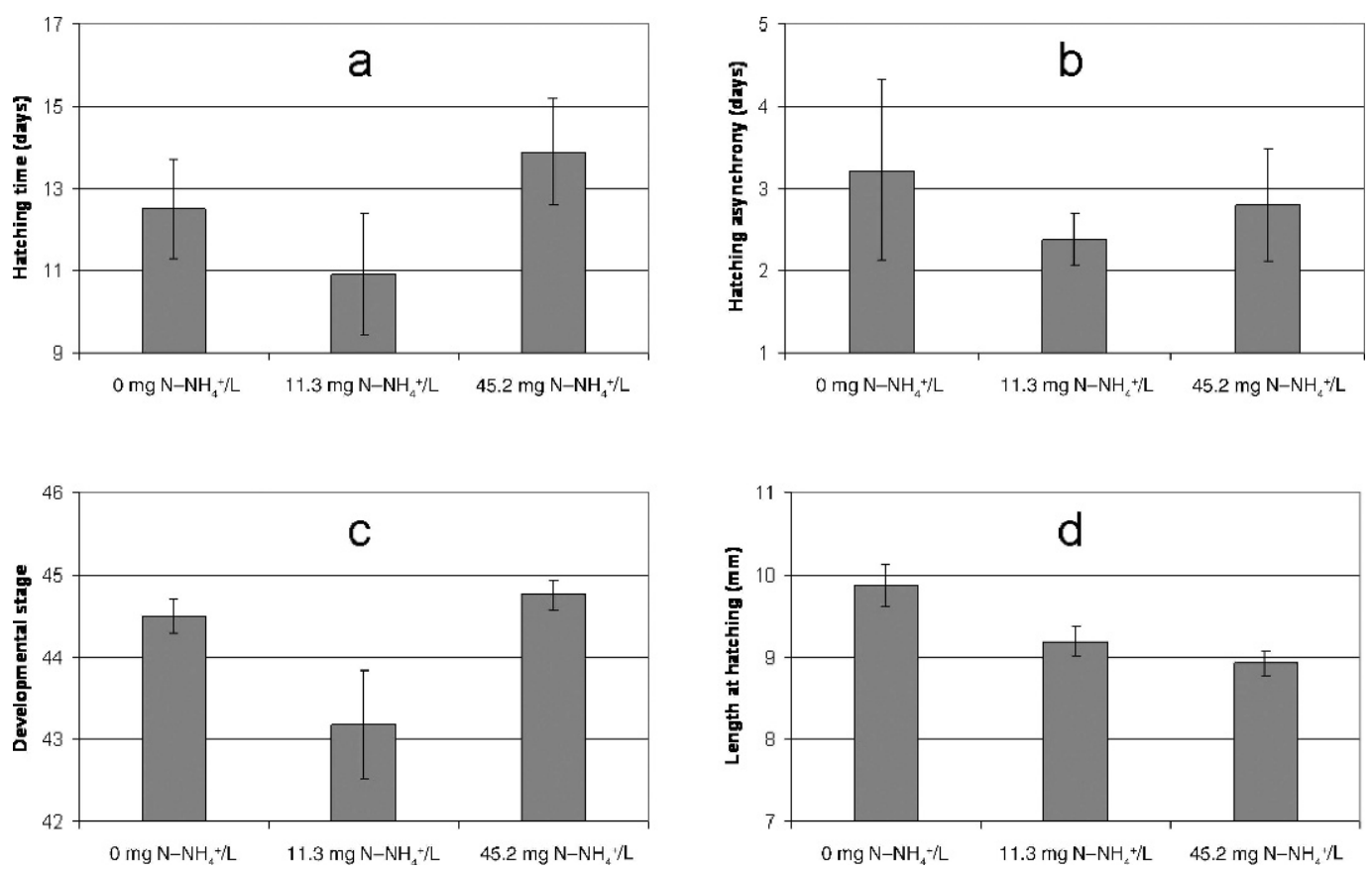

FIG. 2.-Mean (61 SE) values per ammonium nitrate treatment of the hatching variables measured in Lissotriton boscai. (a) Hatching time. (b) Hatching asynchrony. (c) Developmental stage at hatching according to Harrison (1969). (d) Length at hatching.

by both controls and by embryos exposed to the highest ammonium nitrate concentration (Fig. 2c). In spite of these differences, the effect of ammonium nitrate on developmental stage at hatching was only marginally significant when hatching time was taken into account as a covariate (Table 1 ).

Finally, exposure to ammonium nitrate compromised embryonic growth, causing a smaller size of hatchlings (Fig. 2d). The HSD Tukey post-hoc tests revealed that when hatching time was taken into account as a covariate, the length at hatching was significantly reduced with respect to the controls only at the higher ammonium concentration, with the hatchlings exposed to this level being 9.6\% smaller than the controls (control vs. $11.3 \mathrm{mg} \mathrm{N}-\mathrm{NH}_{4}{ }^{+} / \mathrm{L}$ : P 5 0.092; control vs. $45.2 \mathrm{mg} \mathrm{N}-\mathrm{NH}_{4}{ }^{+} / \mathrm{L}$ : P 5 0.019).

\section{Discussion}

Ammonium nitrate at concentrations up to $45.2 \mathrm{mg} \mathrm{N}-\mathrm{NH}_{4}{ }^{+} / \mathrm{L}$ did not cause lethal effects on L. boscai embryos. A few studies have analyzed the effects of ammonium nitrate on amphibian embryos. Contrary to our results, Schuytema and Nebeker (1999a) reported $80 \%$ mortality of Pseudacris regilla embryos exposed to $50.9 \mathrm{mg} \mathrm{N}-\mathrm{NH}_{4}^{+} / \mathrm{L}$ after $4 \mathrm{~d}$, and $53 \%$ mortality of Xenopus laevis after $5 \mathrm{~d}$ of exposure to the same concentration. The L. boscai embryos that we tested were clearly more tolerant, with a mortality of only $20 \%$ at a concentration slightly below that used by Schuytema and Nebeker (1999a). In another paper, Schuytema and Nebeker (1999b) reported a 100\% mortality of Rana aurora embryos after $4 \mathrm{~d}$ of exposure to concentrations $\$ 105 \mathrm{mg} \mathrm{N}-\mathrm{NH}_{4}^{+} / \mathrm{L}$ as ammonium nitrate, although this result is not directly comparable with ours because of the very different levels of nitrate used. Working in field enclosures that were experimentally fertilized with ammonium nitrate, Griffis-Kyle and Ritchie (2007) found a nonsignificant trend for declining hatching rates of Lithobates sylvaticus with increased ammonium concentrations. In agreement with our findings, Puglis and Boone (2007) did not find any 
effect of $11.3 \mathrm{mg} \mathrm{N}-\mathrm{NH}_{4}{ }^{+} / \mathrm{L}$ on the mortality rate of Lithobates catesbeianus. Regarding studies with embryonic urodeles, no lethal effects of ammonium nitrate at $45.2 \mathrm{mg} \mathrm{N}-$ $\mathrm{NH}_{4}^{+} / \mathrm{L}$ were reported for embryos of $\mathrm{T}$. pygmaeus (Ortiz-Santaliestra et al., 2007) and C. Iusitanica (Ortiz-Santaliestra et al., 2011). In line with these results, which point to a high tolerance of urodele embryos to ammonium nitrate, Griffis-Kyle and Ritchie (2007) reported no effects of ammonium nitrate fertilization on $A$. tigrinum hatching.

Other sources of inorganic nitrogen have provided different results in terms of embryonic sensitivity. For example, sodium nitrate produced complete mortality in $\mathrm{P}$. regilla embryos after $4 \mathrm{~d}$ of exposure at $2716 \mathrm{mg} \mathrm{N}-$ $\mathrm{NO}_{3}{ }^{2} / \mathrm{L}$ and in $\mathrm{X}$. laevis embryos exposed for $5 \mathrm{~d}$ at $979.2 \mathrm{mg} \mathrm{N}-\mathrm{NO}_{3}{ }^{2} / \mathrm{L}$ (Schuytema and Nebeker, 1999a). These lethal concentrations, however, are far above the concentrations that exist in the field. More environmentally realistic concentrations (up to $9.03 \mathrm{mg} \mathrm{N}-\mathrm{NO}_{3}{ }^{2} / \mathrm{L}$ ) had no effect on mortality rate of embryos of Lithobates sylvaticus, A. jeffersonianum, A. maculatum, and Bufo americanus (Laposata and Dunson, 1998). Meredith and Whitemann (2008) exposed embryos of A. mexicanum, Hyla chrysoscelis, and Lithobates clamitans to sodium nitrate levels as high as $500 \mathrm{mg} \mathrm{N}-$ $\mathrm{NO}_{3}{ }^{2} / \mathrm{L}$ and reported no significant effects on survival.

This lack of lethal effects at concentrations of nitrate found in areas of high agricultural intensity, or at levels even higher such as those used by Meredith and Whitemann (2008), supports the conclusion that the toxicity of ammonium nitrate is attributable to ammonium rather than to nitrate (e.g., Schuytema and Nebeker, 1999a). In the water, total ammonium occurs in two forms: the less toxic ionized form $\left(\mathrm{NH}_{4}^{+}\right)$and the very toxic un-ionized ammonia $\left(\mathrm{NH}_{3}\right)$, the most toxic form of inorganic nitrogen. Basic $\mathrm{pH}$, high temperatures, and low levels of dissolved oxygen are the main factors contributing to increased proportions of $\mathrm{NH}_{3}$ (Bower and Bidwell, 1978) and therefore to increased toxicity of ammonium nitrate. In our experiments, $\mathrm{pH}$ values were neutral, temperature was maintained at approximately $20 \mathrm{uC}$, and dissolved oxygen was not expected to drop because the water was changed daily and the density of embryos in the aquaria was low. From the experimental conditions, we could expect a low proportion of un-ionized ammonia, which would agree with the low toxicity of ammonium nitrate in terms of mortality reported in the present study.

Although ammonium nitrate did not cause lethal effects, it was associated with shorter $L$. boscai hatchlings. Schuytema and Nebeker (1999a) also observed a negative effect on the size of $\mathrm{P}$. regilla (10-day test) and $\mathrm{X}$. laevis (5day test) embryos exposed to $6.9 \mathrm{mg} \mathrm{N}-\mathrm{NH}_{4}{ }^{+}$/ L. Likewise, Ortiz-Santaliestra et al. (2007) found that ammonium nitrate at a concentration of $45.2 \mathrm{mg} \mathrm{N}-\mathrm{NH}_{4}^{+} / \mathrm{L}$ reduced not only length but also the developmental stage at hatching in T. pygameus.

Exposure to ammonium nitrate may compromise the energy budget by forcing organisms to spend an extra amount of energy in detoxification (Wright and Wright, 1996), which may reduce growth and development. A reduced hatching size may result in decreased survival during the larval stage (e.g., Semlitsch and Gibbons, 1990). Smaller hatchlings may suffer increased risk of predation (Caldwell et al., 1980), be less efficient than larger hatchlings in the search for food (Steinwascher, 1979), and take longer to reach metamorphosis (Griffis-Kyle, 2007; Marco and Blaustein, 1999).

Although environmentally relevant concentrations of ammonium nitrate did not compromise directly L. boscai embryonic survival, sublethal effects such as the ammonium nitrate-related reduction of growth rate, might compromise the animals' ability to deal with natural stressors, thereby reducing their probabilities of survival in natural environments.

Acknowledgments.-The Department of Environment of the Castilla y León regional Government provided the permit for collecting the animals and conducting the experiments (permit E.P.-268/04 [IS]).

\section{Literature Cited}

Ballester, R. 2003. Los humedales de la Región de Murcia: Humedales y ramblas de la Región de Murcia. Dirección General del Medio Natural, Consejería de Agricultura, Agua y Medio Ambiente, Región de Murcia, Murcia, Spain. 
BeEbee, T. J. C. 1996. Ecology and Conservation of Amphibians. Chapman \& Hall, London, UK.

Beebee, T. J. C., and R. A. Griffiths. 2005. The amphibian decline crisis: A watershed for conservation biology? Biological Conservation 125:271-285.

Bower, C. E., AND J. P. Bidwell. 1978. Ionization of ammonia in seawater: Effects of temperature, $\mathrm{pH}$, and salinity. Journal of the Fisheries Research Board of Canada 35:1012-1016.

Caldwell, J. P., J. H. Thorp, and T. O. Jervey. 1980. Predator-prey relationship among larval dragonflies, salamanders, and frogs. Oecologia 46:285-289.

Camargo, J. A., and A. Alonso. 2006. Ecological and toxicological effects of inorganic nitrogen pollution in aquatic ecosystems: A global assessment. Environment International 32:831-849.

Crews, T. E., and M. B. Peoples. 2004. Legume versus fertilizer sources of nitrogen: Ecological tradeoff and human needs. Agriculture, Ecosystems \& Environment 102:279-297.

Diamond, J. M., D. G. Mackler, W. J. Rasnake, and D. GruBER. 1993. Derivation of site-specific ammonia criteria for an effluent-dominated headwater stream. Environmental Toxicology and Chemistry 12:649-658.

Díaz-Paniagua, C. 2009. Tritón ibérico-Lissotriton boscai. In A. Salvador (Ed.), Enciclopedia Virtual de los Vertebrados Españoles. Museo Nacional de Ciencias Naturales, Madrid, Spain, Available at: http://www. vertebradosibericos.org/. Accessed: December 4, 2009.

Driscoll, C. T. 2003. Elevated inputs of reactive nitrogen in the environment. Causes, consequences, and controls. Bioscience 53:311.

Dunson, W. A., R. L. Wyman, and E. S. Corbett. 1992. A symposium on amphibian declines and habitat acidification. Journal of Herpetology 26:349-352.

Egea-Serrano, A., M. Tejedo, and M. Torralva. 2009. Populational divergence in the impact of three nitrogenous compounds and their combination on larvae of the frog Pelophylax perezi (Seoane, 1885). Chemosphere 76:869-877.

European Council. 1998. Council Directive 98/83/EC of 3 November 1998 on the Quality of Water Intended for Human Consumption. Pp. L330/32-L330/54. In Official Journal of the European Communities 05/12/98. Publications Office of the European Union, Luxembourg.

Freda, J., AND W. A. Dunson. 1985. The influence of external cation concentration on the hatching of amphibian embryos in water of low $\mathrm{pH}$. Canadian Journal of Zoology 63:2649-2656.

Galloway, J. N., E. B. Cowling, S. P. Seitzinger, and R. H. Socolow. 2002. Reactive nitrogen: Too much of a good thing? Ambio 31:60-63.

Griffis-Kyle, K. L. 2005. Ontogenic delays in effects of nitrite exposure on tiger salamanders (Ambystoma tigrinum tigrinum) and wood frogs (Rana sylvatica). Environmental Toxicology and Chemistry 24: 1523-1527.

Griffis-KyLE, K. L. 2007. Sublethal effects of nitrite on eastern tiger salamander (Ambystoma tigrinum tigrinum) and wood frog (Rana sylvatica) embryos and larvae: Implications for field populations. Aquatic Ecology 41:119-127.
Griffis-Kyle, K. L., And M. E. Ritchie. 2007. Amphibian survival, growth and development in response to mineral nitrogen exposure and predator cues in the field: An experimental approach. Oecologia 152: 633-642.

Harrison, R. G. 1969. Harrison stages and description of the normal development of the spotted salamander, Ambystoma punctatum (Linn.). Pp. 44-66. In R. G. Harrison (Ed.), Organization and Development of the Embryo. Yale University Press, New Haven, Connecticut, USA.

Holland, E., B. H. Braswell, J. Sulzman, and J. F. LAMARQUE. 2005. Nitrogen deposition onto the United States and Western Europe: Synthesis of observations and models. Ecological Applications 15:38-57.

Huey, D. W., ANd T. L. Beitinger. 1980. Hematological responses of larval Rana catesbeiana to sublethal nitrite exposures. Bulletin of Environmental Contamination and Toxicology 25:574-577.

Jofre, M. B., and W. H. Karasov. 1999. Direct effect of ammonia on three species of North American anuran amphibians. Environmental Toxicology and Chemistry 18:1806-1812.

Jofre, M. B., M. L. Rosenshield, and W. H. Karasov. 2000. Effects of PCB 126 and ammonia, alone and in combination, on green frog (Rana clamitans) and leopard frog (R. pipiens) hatching success, development, and metamorphosis. Journal of the Iowa Academy of Sciences 107:113-122.

Kross, B. C., A. D. Ayebo, and L. J. Fuortes. 1992. Methemoglobinemia: Nitrate toxicity in rural America. American Family Physician 46:183-188.

Laposata, M. M., and W. A. Dunson. 1998. Effects of boron and nitrate on hatching success of amphibian eggs. Archives of Environmental Contamination and Toxicology 35:615-619.

Mann, R., R. V. Hyne, C. B. Choung, and S. P. Wilson. 2009. Amphibians and agricultural chemicals: Review of the risks in a complex environment. Environmental Pollution 157:2903-2927.

Marco, A., and A. R. Blaustein. 1999. The effects of nitrite on behavior and metamorphosis in Cascades frogs (Rana cascadae). Environmental Toxicology and Chemistry 18:946-949.

Marco, A., and M. E. Ortiz-Santaliestra. 2009. Pollution: Impact of reactive nitrogen on amphibians. Pp. 3145-3185. In H. Heatwole and J. W. Wilkinson (Eds.), Amphibian Biology, Volume 8, Amphibian Decline: Diseases, Parasites, Maladies and Pollution. Surrey Beatty \& Sons, Baulkham Hills, New South Wales, Australia.

Massal, L. R., J. W. Snodgrass, and R. E. Casey. 2007. Nitrogen pollution of stormwater ponds: Potential for toxic effects on amphibian embryos and larvae. Applied Herpetology 4:19-29.

Meredith, C. S., and H. H. Whiteman. 2008. Effects of nitrate on embryos of three amphibian species. Bulletin of Environmental Contamination and Toxicology 80:529-533.

Ortiz, M. E., A. Marco, N. Saiz, and M. Lizana. 2004. Impact of ammonium nitrate on growth and survival of six European amphibians. Archives of Environmental Contamination and Toxicology 47:234-239. 
Ortiz-Santaliestra, M. E., M. J. Fernández-Benéitez, M. Lizana, And A. Marco. 2010. Adaptation to osmotic stress provides protection against ammonium nitrate in Pelophylax perezi embryos. Environmental Pollution 158:934-940.

Ortiz-Santaliestra, M. E., M. J. Fernández-Benéitez, M. Lizana, AND A. Marco. In press. Influence of a combination of agricultural chemicals on embryos of the endangered gold-striped salamander (Chioglossa Iusitanica). Archives of Environmental Contamination and Toxicology. DOI 10.1007/s00244-010-9570-x.

Ortiz-Santaliestra, M. E., A. Marco, M. J. FernándezBenéitez, and M. Lizana. 2007. Effects of ammonium nitrate exposure and water acidification on the dwarf newt: The protective effect of oviposition behaviour on embryonic survival. Aquatic Toxicology 85:251-257.

Ortiz-Santaliestra, M. E., A. Marco, M. J. FernándezBenéitez, and M. Lizana. 2009. Alteration of courtship behavior because of water acidification and minor effect of ammonium nitrate in the Iberian newt (Lissotriton boscai). Environmental Toxicology and Chemistry 28:1500-1505.

Ortiz-Santaliestra, M. E., A. Marco, and M. Lizana. 2005. Sensitivity and behavior of the Iberian newt, Triturus boscai, under terrestrial exposure to ammonium nitrate. Bulletin of Environmental Contamination and Toxicology 75:662-669.

Puglis, H. J., ANd M. D. Boone. 2007. Effects of a fertilizer, an insecticide, and a pathogenic fungus on hatching and survival of bullfrog (Rana catesbeiana) tadpoles. Environmental Toxicology and Chemistry 26:2198-2201.

Schuytema, G. S., AND A. V. Nebeker. 1999a. Comparative effects of ammonium and nitrate compounds on Pacific treefrog and African clawed frog embryos.
Archives of Environmental Contamination and Toxicology 36:200-206.

Schuytema, G. S., AND A. V. NebeKer. 1999b. Effects of ammonium nitrate, sodium nitrate, and urea on redlegged frogs, Pacific treefrogs, and African clawed frogs. Bulletin of Environmental Contamination and Toxicology 63:357-364.

Semlitsch, R. D., And J. W. GibBons. 1990. Effects of egg size on success of larval salamanders in complex aquatic environments. Ecology 71:1789-1795.

Sokal, R. R., and F. J. Rohlf. 1995. Biometry: The Principles and Practices of Statistics in Biological Research, 3rd Edition. W. H. Freeman, New York, New York, USA.

Steinwascher, K. 1979. Competitive interactions among tadpoles: Responses to resource levels. Ecology 60:1172-1183.

Vitousek, P. M., J. Aber, R. W. Howarth, G. E. Likens, P. A. Matson, D. W. Schindler, W. H. Schlesinger, and D. Tilman. 1997. Human alteration of the global nitrogen cycle: Causes and consequences. Issues in Ecology 1:1-16.

Wright, P. M., AND P. A. WRight. 1996. Nitrogen metabolism and excretion in bullfrog (Rana catesbeiana) tadpoles and adults exposed to elevated environmental ammonia levels. Physiological Zoology 69:1057-1078.

YoshizaKi, N. 1978. Disintegration of the vitelline coat during the hatching process in the frog. Journal of Experimental Zoology 203:127-134. 